\title{
Priapism associated with the addition of risperidone to methylphenidate monotherapy: a case report
}

\author{
Hatice Unver, ${ }^{1}$ Nursu Cakin Memik, ${ }^{1}$ Emrah Simsek $^{2}$ \\ ${ }^{1}$ Department of Child and Adolescent Psychiatry, Kocaeli University Faculty of Medicine, Kocaeli, Turkey \\ ${ }^{2}$ Department of Urology, Kocaeli University Faculty of Medicine, Kocaeli, Turkey
}

\begin{abstract}
Priapism is a state of prolonged and unwanted erection without sexual stimulation or desire. Priapism may occur with a variety of diseases or as a side effect of medication. Immediate diagnosis and treatment is essential, as ischemia of cavernous tissues results in erectile dysfunction. Described in the present report is a 12-year-old male with priapism associated with the addition of risperidone to methylphenidate monotherapy. Priapism decreased and disappeared following discontinuation of drug therapy and implementation of cavernous drainage. To our knowledge, the present is the first report to describe priapism associated with the addition of risperidone to methylphenidate monotherapy. It is hoped that attention will be drawn to the risk of priapism caused by the combination of these psychopharmacologic agents.
\end{abstract}

Key words: Methylphenidate; priapism; risperidone.

$\mathrm{P}$ riapism is defined as persistent, painful, abnormal tumescence that occurs without sexual stimulation and does not subside after sexual intercourse or masturbation [1]. The condition was named after Priapus, a mythical hero known as the god of fertility, the son of Aphrodite and Dionysus, whose oversized, permanent erection was viewed as a symbol of masculinity and power [2].

Priapism can occur at any age. Sickle cell anemia, malignancy, and perineal trauma are the most common causes of priapism in children and adolescents [3]. Priapism can lead to permanent and irre-

versible erectile dysfunction, urinary retention, and gangrene $[1,3]$, as well as impotence in $40-50 \%$ of patients, due to ischemia and fibrosis developing in the corpus cavernosum [4]. A large and increasing number of drugs reportedly cause the condition, including anticoagulants, antihypertensives, antidepressants, anxiolytics, antipsychotics, intracavernous drugs, alcohol, and narcotics such as cocaine and marijuana $[1,3-6]$.

Priapism is connected to the mechanism of alpha-1 receptor blockade. Traditional alpha- 1 receptor blockers such as prazosin are known to cause

This article was presented as a poster at the $5^{\text {th }}$ International Congress on Psychopharmacology in 2013.

Received: March 23, 2015 Accepted: August 02, 2015 Online: May 10, 2017

Correspondence: Dr. Hatice UNVER. Kocaeli Universitesi Tip Fakultesi,

Cocuk ve Ergen Psikiyatrisi Anabilim Dali, Kocaeli, Turkey.

Tel: +90 262 - 3038702 e-mail: drhaticeunver@gmail.com

(c) Copyright 2017 by Istanbul Northern Anatolian Association of Public Hospitals - Available online at www.kuzeyklinikleri.com 
priapism. Trazodone is the psychotropic medication most commonly associated with priapism, with an incidence of 1 in 6000 [7].

To our knowledge, the present is the first report to describe priapism associated with methylphenidate and risperidone treatment, though 7 cases of priapism in adolescents taking psychotropic medications have been reported. The condition has occurred in adolescents taking risperidone and paroxetine, risperidone and lithium, olanzapine and methylphenidate, risperidone monotherapy, oxcarbazepine in combination with aripiprazole and lithium, osmotic controlled-release methylphenidate hydrochloride, and immediate-release methylphenidate [5-13].

The case of a 12-year-old patient who developed priapism after using methylphenidate and risperidone is described in the present report.

\section{CASE REPORT}

Four years prior to the submission of the present report, the patient, then 8 years old, was diagnosed with attention deficit-hyperactivity disorder and treatment of OROS methylphenidate $18 \mathrm{mg} /$ day was initiated, taken in the morning. Dosage was increased to 27,36 , and $54 \mathrm{mg}$ due to unsatisfactory clinical response, and dosage of $54 \mathrm{mg} /$ day has been taken for the past 1.5 years. Risperidone $0.5 \mathrm{mg} /$ day was added due to the development of symptoms of behavioral disorder. A week after the addition, dosage of risperidone was increased to $2 \mathrm{x}$ $0.5 \mathrm{mg} /$ day due to unsatisfactory clinical response. Drugs were taken consistently. On the $22^{\text {nd }}$ day of treatment, the patient developed a painful erection upon waking, without sexual stimulation. Three hours later, the patient was admitted by emergency services and underwent cavernous drainage, after which slow infusion of $10 \%$ diluted epinephrine was injected into the corpus cavernosum to reduce pain and erection. Blood flow improved, however, the patient experienced a second erection while still in the hospital, and drainage was repeated, after which the erection improved. Though a third erection did occur, blood flow was normal, and surgical intervention was not necessary. Shunt surgery was not attempted, due to the age of the patient. Medical treatment was terminated after hospital admis- sion. The patient was discharged the day after the procedure with a $50 \%$ improvement in his erection. However, when the patient was admitted for control on the $3^{\text {rd }}$ and $5^{\text {th }}$ day after discharge, an erection of $50 \%$ was present. The erection disappeared on the $7^{\text {th }}$ day after initial discharge. Upon investigation, the patient was found to have taken no illicit drug or unprescribed medical agent, and to have no medical condition associated with priapism, including the hemoglobinopathies, sickle cell anemia, or chronic myeloid leukemia. Upon detailed medical examination, methylphenidate and risperidone treatment was suspected as the cause of priapism. After discontinuation of psychostimulant and antipsychotic treatment, $50 \mathrm{mg} /$ day atomoxetine treatment was initiated due to increase in symptoms of attention deficit-hyperactivity disorder. Symptoms improved, and prolonged erection was not repeated. The patient and his parents were provided with detailed information regarding the present report and signed a detailed written consent form.

\section{DISCUSSION}

Priapism is a condition that requires immediate attention, as it can lead to devastating long-term consequences, including impotence, urinary retention, and gangrene $[11,12]$. Penile erection is a result of neural and vascular factors, involving an increased sacral parasympathetic tone that leads to increased blood flow into the arterioles and sinusoids, at which point the veins are compressed. Priapism results from alpha-1-adrenergic blockade in the corpora cavernosum, leading to parasympathetic, mediated arterial dilation and the inhibition of the sympathetic system. The result is intracavernosal stasis due to inadequate venous outflow caused by obstruction of the subtunical venules, causing hypoxia, acidosis, and pain [5].

The cause of priapism may be primary, secondary, or idiopathic. Priapism with primary etiology is not accompanied by a disorder of physical or psychological origin responsible for the prolonged erection. Secondary priapism is induced by factors directly or indirectly affecting the erection, such as traumatic, neoplastic, hematologic, surgical, neurologic, toxic, allergic, infective, or pharmacologic complications $[1,14]$. Arterial high- and low-flow priapism occur. High-flow priapism leads to retention of well-oxy- 
genated blood in the corpus cavernosum. The etiology remains unclear, though pharmacological, traumatic, and neurologic diseases have been proposed. High-flow priapism is painless and does not cause ischemia, as opposed to low-flow or veno-occlusive priapism, which results in hypoxia and tissue ischemia. If the blockade continues, it will lead to irreversible changes and permanent damage. Priapism caused by antipsychotics is usually low-flow, typically lasting more than 4-6 hours, and is associated with a much higher likelihood of irreversible impotence $[5,15]$. The present patient suffered from lowflow priapism. Blood flow returned to normal and pain decreased after drainage.

Various therapeutic options exist, including mechanical (sustained perineal compression and ice packs), pharmacological (intracavernous, venous, or oral drug therapy), radiological (selective transcatheter embolization therapy), and surgical options (arterial ligation or arteriovenous shunts). Less invasive procedures are being conducted with increasing rates of success, and the need for surgical intervention is decreasing [16]. The present patient suffered from pain associated with tissue hypoxia and acidosis, requiring urgent therapeutic intervention of irrigation and corporeal blood aspiration of up to $150-200 \mathrm{ml}$.

Priapism may occur at any time during course of treatment involving psychotropic drugs and may occur without change of dose. Priapism can be considered an idiosyncratic reaction, as it is correlated neither with dosage nor duration of psychotropic drug use [5].

The effects of multiple neurotransmitters, particularly those affecting dopamine reuptake and release in the striatum, form the mechanism of priapism following OROS methylphenidate treatment. OROS methylphenidate hydrochloride is an osmotic, controlled-release delivery system designed for once-daily oral dosing. Following usage, a gradual increase in mean methylphenidate plasma concentration peaks at 6-8 hours in an event lasting an average of 12 hours. It has been demonstrated that common adverse effects of methylphenidate are insomnia, decreased appetite, weight loss, abdominal pain, headache, anxiety, tendency to cry, and irritability. Increases in systolic and diastolic blood pressure, as well as heart rate have been reported and may be related to dose $[17,18,19]$. While priapism is not a common side effect, it has been reported with use of osmotic, controlled-and immediate-release methylphenidate $[8,10,13,20]$. In the present case, priapism developed only after addition of risperidone to OROS methylphenidate monotherapy.

Priapism has been reported in patients with unusual susceptibility to side effects taking multiple antipsychotics. The mechanism of priapism associated with atypical antipsychotics such as risperidone is not clear, but is thought to be related to alpha-adrenergic blockage mediated by the alpha receptors in the corpora cavernosum [12]. Risperidone has nearly the highest affinity for the alpha-adrenergic receptor among atypical antipsychotics, and has been associated with priapism in 20 cases. Priapism can occur soon after initiation of risperidone treatment, after stable doses of risperidone have been taken for long periods of time, after a change in dose, or after the addition of another medication, including other antipsychotics, lithium, or serotonin-specific reuptake inhibitors $[5,7,12]$.

It has been proposed that psychopharmacologic agents affect sexuality in 3 steps, either positively or negatively, and that the effects of dopaminergic agents are especially prevalent on the $1^{\text {st }}$ and $2^{\text {nd }}$. In the first step, the libido is raised by amphetamine and methylphenidate, causing dopamine discharge. Sexual stimulation, the second step, may be triggered by certain dopaminergic agents [21].

As a result, in the present case, the addition of risperidone to OROS methylphenidate monotherapy caused prolonged erection. It is suggested that the risk of priapism may increase when risperidone is added to methylphenidate treatment. As priapism can lead to permanent and irreversible erectile dysfunction, clinicians should be aware of this side effect and counsel children or adolescent patients and their families accordingly, in order to improve the adaptation of the treatment. Education of patients and families would increase awareness, promote early reporting, and help reduce long-term consequences, including impotence and gangrene.

Conflict of Interest: No conflict of interest was declared by the authors.

Financial Disclosure: The authors declared that this study has received no financial support. 
Authorship contributions: Concept - H.U.; Design - H.U.; Supervision - N.C.M.; Data collection \&/or processing - H.U., E.S.; Analysis and/or interpretation - N.C.M.; Literature search - H.U.; Writing - H.U.; Critical review - N.C.M.

\section{REFERENCES}

1. Van der Horst C, Stuebinger H, Seif C, Melchior D, Martínez-Portillo FJ, Juenemann KP. Priapism - etiology, pathophysiology and management. Int Braz J Urol 2003;29:391400.

2. Papadopoulos I, Kelâmi A. Priapus and priapism. From mythology to medicine. Urology. 1988;32:385-6.

3. Pryor J, Akkus E, Alter G, Jordan G, Lebret T, Levine L, et al. Priapism. J Sex Med 2004;1:116-20.

4. Muneer A, Minhas S, Arya M, Ralph DJ. Stuttering priapism--a review of the therapeutic options. Int J Clin Pract 2008;62:126570.

5. Sood S, James W, Bailon MJ. Priapism associated with atypical antipsychotic medications: a review. Int Clin Psychopharmacol 2008;23:9-17.

6. Munarriz R, Hwang J, Goldstein I, Traish AM, Kim NN. Cocaine and ephedrine-induced priapism: case reports and investigation of potential adrenergic mechanisms. Urology 2003;62:187-92.

7. Compton MT, Miller AH. Priapism associated with conventional and atypical antipsychotic medications: a review. J Clin Psychiatry 2001;62:362-6.

8. Husár M, Zerhau P. Priapism in childhood--case report of 14-year-old boy. [Article in Czech] Rozhl Chir 2006;85:32930. [Abstract]

9. Prabhuswamy M, Srinath S, Girimaji S, Seshadri S. Risperidone-induced priapism in a 12-year-old boy with schizophrenia. J Child Adolesc Psychopharmacol 2007;17:539-40.

10. Schwartz RH, Rushton HG. Stuttering priapism associated with withdrawal from sustained-release methylphenidate. J Pe- diatr 2004;144:675-6.

11. Negin B, Murphy TK. Priapism associated with oxcarbazepine, aripiprazole, and lithium. J Am Acad Child Adolesc Psychiatry 2005;44:1223-4.

12. Patel AG, Mukherji K, Lee A. Priapism associated with psychotropic drugs. Br J Hosp Med 1996;55:315-9.

13. Çakın Memik N, Yıldız Ö, Şişmanlar Ş, Karakaya I, Ağaoğlu B. Metilfenidat kullanımı ile meydana gelen priapizm: bir olgu sunumu. Türk Pediatri Dergisi 2010;52:435-9.

14. Shantha TR, Finnerty DP, Rodriquez AP. Treatment of persistent penile erection and priapism using terbutaline. J Urol 1989;141:1427-9.

15. Witt MA, Goldstein I, Saenz de Tejada I, Greenfield A, Krane RJ. Traumatic laceration of intracavernosal arteries: the pathophysiology of nonischemic, high flow, arterial priapism. J Urol 1990;143:129-32.

16. Bastuba MD, Saenz de Tejada I, Dinlenc CZ, Sarazen A, Krane RJ, Goldstein I. Arterial priapism: diagnosis, treatment and longterm followup. J Urol 1994;151:1231-7.

17. Kimko HC, Cross JT, Abernethy DR. Pharmacokinetics and clinical effectiveness of methylphenidate. Clin Pharmacokinet 1999;37:457-70.

18. Heal DJ, Cheetham SC, Smith SL. The neuropharmacology of ADHD drugs in vivo: insights on efficacy and safety. Neuropharmacology 2009;57:608-18.

19. Özcan T, Toros F, Pekdemir H, Çiçek D, Çamsarı A, Yurttaş M, et al. The Effect of Methylphenidate on Time Domain Heart Rate Variability in the Treatment of Attention Deficit and Hyperactivity Disorder. Çocuk ve Gençlik Ruh Sağlığı Dergisi 2004;11:117-22.

20. Coskun M, Zoroglu S. A report of two cases of sexual side effects with OROS methylphenidate. J Child Adolesc Psychopharmacol 2009;19:477-9.

21. Stahl SM. Cinsiyete özgü ve cinsel işlevle ilgili psikofarmakoloji. Temel psikofarmakoloji içinde (Çev. Taneli B, Taneli Y) İstanbul: Yelkovan yayınc1lı 2003;539-69. 